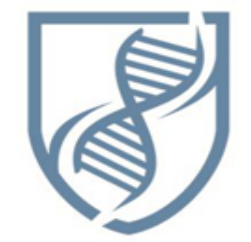

Journal of Bioscience and Applied Research
JBAAR

WWW.JBAAR.ORG

\title{
Survey on the parasites infested crayfish Procambarus clarkii, Girard,1852 (Crustacea, Cambaridae) in Egypt
}

\author{
Shimaa M. Abd El-Moaty, Hesham M. Sharaf, Abd El-Monem M.Khalil and Shimaa S. Ahmed. \\ Department of Zoology, Faculty of Science, Zagazig University \\ (Email: sharaf_hesham@yahoo.com)
}

\begin{abstract}
A parasitological survey on 1474 fresh water crayfish Procambarus clarkii was carried out during the period from January 2013 till May 2014 from different canals at Sharkia, Dakahlia and Kafr El-Sheikh Provinces in Egypt. Out of the examined crayfish , 8 were found to be infected with ectoparasitic protozoan Epistylis cambari on the gill filaments with percentage of infection $0.54 \%$. Infection rates were varied between investigated areas, the percentages of infection were $0.21 \%, 0.57 \%$ and $2.7 \%$ at Sharkia, Dakahlia and Kafr El- Sheikh provinces respectively. Regarding to the seasonal prevalence of Epistylis cambari in examined crayfishes the peak of infection at Sharkia Province was recorded in summer (3.5\%) , while at Dakahlia and Kafr El- Sheikh Provinces was detected in spring (1.13\%) and (5.12\%) respectively. The present study revealed that 11 out of $1474(0.88 \%)$ were infected by one or more parasitic nematode larvae Strongyloides stercoralis that were observed in hemoceol of crayfish .The percentages of infection were $0.31 \%$, $2.3 \%$ and $1.3 \%$ at Sharkia, Dakahlia and Kafr El-Sheikh Provinces respectively. Concerning to the seasonal prevalence of nematode larvae in examined crayfish, the peak of infection at Sharkia Province was detected in spring (4.5\%), while at Dakahlia Province was in summer (3.2\%) and at Kafr El-Sheikh Province was in spring (1.5\%). No infection was detected in winter and autumn.
\end{abstract}

Keywords: Parasites, Crayfish, Protozoa, Nematoda, Larvae, Crustacea.

\section{Introduction}

Fresh water crayfish are wide spread crustaceans occurring on all continents except Antarctica. Several species have been used for aquaculture purposes and more recently, there has been an increase in the sale of crayfish for aquaria (Longshaw, 2011). The fresh water crayfish Procambarus clarkii is a newly invasive species accidentally introduced in 1980 to Egypt, which has rapidly become established along the River Nile. It has rabidly expanded in all freshwater ecosystems including streams, ponds and mashes with polluted or clean water, with outstanding power to adapt to new habitats and became an important component of the local aquatic fauna (Soliman et al., 1998; Hamdy, 2004). Research focusing on the dynamics of the communities of the parasites has traditionally paid more attention to vertebrate definitive hosts (Esch et al., 1990). Few projects have been carried out regarding intermediate hosts. These hosts because of the predator- prey pathways, which lead to parasite transmission, have a closer ecological association with the definitive host (Wetzel and Esch, 1996). Many helminthic parasites use fresh water crayfish as second intermediate host (Lefebvre and Poulin, 2005). Crayfish is a highly nutritive and delicious food that consumed by a big sector of the population in different countries in the world. The present study was carried out to spot the light on some parasites infecting fresh water crayfish and their role in the ecosystem.

\section{Materials and Methods}

A total of 1474 fresh water crayfish procambarus clarkii were collected and examined for the presence of parasites. Specimens were collected from different canals belonging to different localities at Sharkia Province, these samples included 787 crayfish from Moias Canal at Zagazige City ,110 from Kafr El-Hosr Canal at Zagazige City and 77 from El-Azyzyia Canal at Menia El-Kamh City , while 350 specimens from Mit-Ghamr City, Dakahlia Province and 
150 crayfish collected from Kafr El-Sheikh Province from the period extending from January 2013 till May 2014.The specimens were brought fresh to Zoology Department, Faculty of Science ,Zagazige University and in the laboratory they kept in artificially aerated glass aquaria (38h x 90L x 55w cm) . Fresh parts of different organs (gills, hepatopancreas, antennal gland digestive tract and muscles) were immersed in $0.9 \%$ saline solution and compressed between two slides then examined under dissecting microscope to detect the parasitic protozoan. Small portion of the infected gills were fixed in $10 \%$ buffered formalin then embedded in paraffin wax blocks, sectioned at $5 \mu$,after that stained with hematoxylin and eosin and the light photomicrographs were taken with standard lietz Dialux 20 EB research microscope. The nematode larvae were recovered from the hemoceal and the body cavity of the infected crayfish, these larvae were washed several times in saline solution and kept in refrigerator for killing and stretching. The larvae were treated with $5 \%$ glycerol and $70 \%$ ethyl alcohol, then cleared in lacto phenol and lastly mounted in polyvinyl alcohol ( Whittlock, 1966) and light photomicrographs were taken. The mounted larvae were morphologically identified according to Anderson (1984) and Frantisek (1994). Statistical analysis was performed using SPSS program 14.0.

\section{Results}

\section{Occurrence of protozoan parasite Epistylis cambari in} examined crayfish.

Statistical analysis of data in table (1) revealed that there were highly significant differences in percentage of infected crayfish with ectoparasitic protozoan Epistylis cambari among different localities at Sharkia, Dakahlia and Kafr El-Sheikh Provinces. From 1474 examined fresh water crayfish Procambarus clarkii, 8 were found to be infected with Epistylis cambari on the gill filaments (Figs.1 and 2) with percentage of infection $0.54 \%$. The total percentage of infection at Sharkia Province equal to $0.21 \%$ with infection rate 2 out of 974, the percentage of infection was $0 \%, 1.8 \%, 0 \%$ at Moias Canal, Zagazige, Kafr El-Hosr, Zagazige, and El-Azyzyia, Menia El-Kamh respectively.While in Mit-Ghamr City at Dakahlia Province was $0.57 \%$ with infection rate 2 out of 350, and in Kafr ElSheikh Province was $2.7 \%$ with infection rate 4 out of 150 crayfish.

\section{Seasonal prevalence of protozoan parasites Epistylis cambari in examined crayfish.}

Regarding to the seasonal prevalence of protozoan parasite Epistylis cambari in examined crayfish at Sharkia, Dakahlia and Kafr El-Sheikh Provinces, the peak of infection at Sharkia Province was detected in summer (3.6\%) and no infection detected in winter, spring and autumn (table 2 a). While at Dakahlia Province the peak of infection was detected in spring (1.14\%) followed by summer $(0.57 \%)$ and no infection detected in winter and autumn (table 2 b). At Kafr El-Sheikh Province the peak of infection was detected in spring (5.13\%) followed by summer (3.8\%) and no infection detected in winter and autumn (table 2c).

\section{Occurrence of nematode larvae Strongyloides stercoralis} in examined crayfish.

A parasitological survey on 1474 crayfish collected from different canals at Sharkia , Dakahlia and Kafr ElSheikh Provinces revealed that 13 out of 1474 with the percentage of infection $(0.88 \%)$ were infected by one or more parasitic nematode larvae Strongyloides stercoralis that were observed in hemoceol and body cavity of freshwater crayfish Procambarus clarkii . Table (3) show the occurrence and intensity of infection with Strongyloides stercoralis larvae in fresh water crayfish at different localities of Sharkia , Dakahlia and Kafr El-Sheikh provinces.The percentage of infection at Sharkia Province was $0.31 \%$ ( 3 out of 974 ), the percentage of infection was $0 \%, 2.7 \%$ and $0 \%$ at Moias Canal, Zagazige, Kafr ElHosr, Zagazige and El-Azyzyia, Menia El-Kamh respectively, while infection rate at Dakahlia Province was $2.3 \%$ ( 8 out of 350) and the percentage of infection at Kafr El-Skeikh Province was 1.3\% ( 2 out of 150 ). Statistical analysis of data in table (3) revealed that there were highly significant differences in percentage of infected crayfish with nematode larvae Strongyloides stercoralis among different localities at Sharkia, Dakahli and Kafr El- Sheikh Provinces.

\section{Seasonal prevalence of nematode larvae Strongyloides} stercoralis in examined crayfish.

Regarding to the seasonal prevalence of Strongyloides stercoralis larvae in examined crayfish at Sharkia, Dakahlia and Kafr El-Sheikh Provinces, the peak of infection at Sharkia Province was detected in spring (4.5\%) followed by summer $(2.6 \%)$, and no infection detected in winter and autumn (table $4 \mathrm{a}$ ). At Dakahlia Province the peak of infection was detected in summer (3.2\%) followed by spring $(1.7 \%)$, the lowest one was observed in autumn(1.5\%) and no infection was detected in winter (table 4 b). At Kafr El-Sheikh Province, the peak of infection was detected in spring (1.5\%) followed by summer $(1.3 \%)$ and no infection was detected in autumn and winter (table $4 \mathrm{c}$ ). The common trend was that the infection rates peak in the warmer seasons of the year ( summer and spring) and no infection was detected in the colder seasons (winter and autumn).

\section{Description of nematode larva.}

Order: Rhabditida.

Family: Strongyloididae.

Genus: Strongyloides.

A) Second rhabditiform larva, its body length is 0.2 $\mathrm{mm}$, it has a short buccal cavity and short esophagus. The posterior tip of this larva is blunter (Fig.3).

B) The filariform larva of Strongyloides stercoralis is much longer and more slender than its rhabditioid stage, its 
body length is about $0.6 \mathrm{~mm}$. It is easily recognized by its long esophagus-equal in length to the intestine and by its blunt tail. This stage normally occurs in soil or in cultured feces. Other diagnostic characteristics include a prominent genital primordium, in addition a short buccal cavity (Figs.4,5 and 6).

Table (1): Occurrence of protozoan parasite Epistylis cambari in examined crayfish in different localities at Sharkia, Dakahlia and kafr El-Sheikh Provinces.

\begin{tabular}{|c|c|c|c|c|}
\hline Spices & Localities & $\begin{array}{l}\text { No. of } \\
\text { examined } \\
\text { specimens }\end{array}$ & $\begin{array}{l}\text { No. of } \\
\text { infected } \\
\text { specimen } \\
\text { s } \\
\end{array}$ & $\begin{array}{l}\text { \% of } \\
\text { infection }\end{array}$ \\
\hline $\begin{array}{l}\text { Fresh water } \\
\text { crayfish }\end{array}$ & $\begin{array}{l}\text { A) Sharkia } \\
\text { Province }\end{array}$ & 974 & 2 & 0.21 \\
\hline \multirow{6}{*}{$\begin{array}{l}\text { Procambarus } \\
\text { clarkii }\end{array}$} & $\begin{array}{l}\text { 1- Moias } \\
\text { Canal }\end{array}$ & 787 & 0 & 0 \\
\hline & $\begin{array}{l}\text { 2-kafr El- } \\
\text { Hosr }\end{array}$ & 110 & 2 & 1.8 \\
\hline & $\begin{array}{l}\text { 3-El- } \\
\text { Azyzyia, } \\
\text { Menia El- } \\
\text { Kamh } \\
\end{array}$ & 77 & 0 & 0 \\
\hline & $\begin{array}{l}\text { B) Dakhlia } \\
\text { Province }\end{array}$ & \multirow[t]{2}{*}{350} & \multirow[t]{2}{*}{2} & \multirow[t]{2}{*}{0.57} \\
\hline & $\begin{array}{l}\text { 1-Mit- } \\
\text { Ghamr city }\end{array}$ & & & \\
\hline & $\begin{array}{l}\text { C) Kafr } \\
\text { El-Sheikh } \\
\text { Province }\end{array}$ & 150 & 4 & 2.7 \\
\hline Total & & 1474 & 8 & 0.54 \\
\hline
\end{tabular}

Table (2- a, b and c): Seasonal prevalence of protozoan parasite Epistylis cambari in examined crayfish in Sharkia , Dakhlia and Kafr El- Sheikh Provinces.

Table (2 a)

\begin{tabular}{|l|l|l|l|}
\hline Season & \multicolumn{3}{|c|}{ Sharkia Province } \\
\hline & $\begin{array}{l}\text { No. of examined } \\
\text { specimens }\end{array}$ & $\begin{array}{l}\text { No. of infected } \\
\text { specimens }\end{array}$ & \% of infection \\
\hline Spring & 35 & 0 & 0 \\
\hline Summer & 56 & 2 & 3.6 \\
\hline Autumn & 11 & 0 & 0 \\
\hline Winter & 8 & 0 & 0 \\
\hline Total & 110 & 2 & 1.8 \\
\hline
\end{tabular}

\section{Table (2 b).}

\begin{tabular}{|l|l|l|l|}
\hline Season & \multicolumn{2}{|l|}{ Dakhlia Province } & \% of infection \\
\hline & $\begin{array}{l}\text { No. of examined } \\
\text { specimens }\end{array}$ & $\begin{array}{l}\text { No. of infected } \\
\text { specimens }\end{array}$ & 1.14 \\
\hline Spring & 88 & 1 & 0.57 \\
\hline Summer & 175 & 1 & 0 \\
\hline Autumn & 66 & 0 & 0 \\
\hline Winter & 21 & 0 & 0.57 \\
\hline Total & 350 & 2 & \\
\hline
\end{tabular}

Table (2 c) .

\begin{tabular}{|l|l|l|l|}
\hline Season & \multicolumn{2}{|l|}{ Kafr El-Sheikh Province } \\
\hline & $\begin{array}{l}\text { No. of examined } \\
\text { specimens }\end{array}$ & $\begin{array}{l}\text { No. of infected } \\
\text { specimens }\end{array}$ & of infection \\
\hline Spring & 39 & 2 & 5.13 \\
\hline Summer & 52 & 2 & 3.8 \\
\hline Autumn & 40 & 0 & 0 \\
\hline Winter & 19 & 0 & 0 \\
\hline Total & 150 & 4 & 2.7 \\
\hline
\end{tabular}

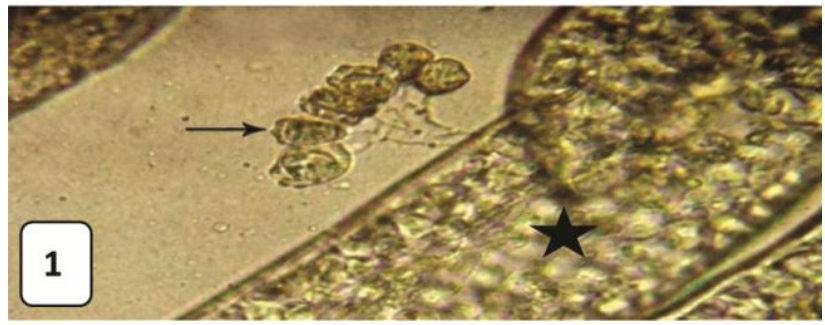

Figure (1): light micrograph of wet preparation of gills showing Epistylis cambari (arrow) among the gillfilaments (star) (400x).

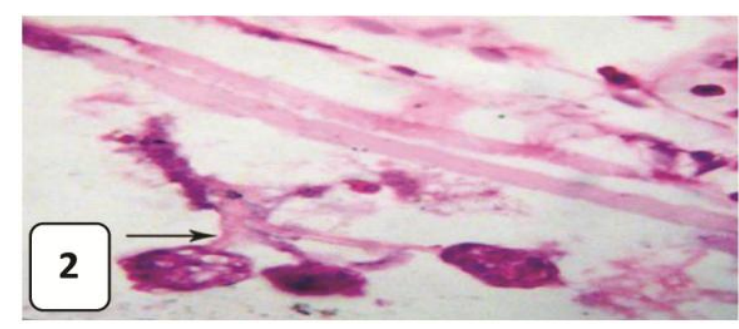

Figure (2): Light micrograph of gills showing Epistylis cambari (arrow) among the gill filaments (H \&E)(400x).

Table (3): Occurrence of nematode larvae Strongyloides stercoralis in examined crayfish in different localities at Sharkia, Dakahlia and Kafr El-Sheikh Provinces.

\begin{tabular}{|c|c|c|c|c|}
\hline Spices & Localities & $\begin{array}{c}\text { No. of } \\
\text { examined } \\
\text { specimens }\end{array}$ & $\begin{array}{c}\text { No. of } \\
\text { infected } \\
\text { specimens }\end{array}$ & $\begin{array}{c}\text { \% of } \\
\text { infectio } \\
\mathbf{n}\end{array}$ \\
\hline $\begin{array}{c}\text { Fresh water } \\
\text { crayfish }\end{array}$ & $\begin{array}{c}\text { A) Sharkia } \\
\text { Province }\end{array}$ & 974 & 3 & 0.31 \\
\hline $\begin{array}{c}\text { Procambarus } \\
\text { clarkii }\end{array}$ & 1- Moias Canal & 787 & 0 & 0 \\
\cline { 2 - 5 } & 2-kafr El-Hosr & 110 & 3 & 2.7 \\
\cline { 2 - 5 } & $\begin{array}{c}\text { 3-El- } \\
\text { Azyzyia,Menia } \\
\text { El-Kamh }\end{array}$ & 77 & 0 & 0 \\
\cline { 2 - 5 } & $\begin{array}{c}\text { B) Dakhlia } \\
\text { province }\end{array}$ & 350 & 8 & 2.3 \\
\cline { 2 - 5 } & $\begin{array}{c}\text { 1-Mit-Ghamr } \\
\text { city }\end{array}$ & & 2 & 1.3 \\
\cline { 2 - 5 } & $\begin{array}{c}\text { C) Kafr El- } \\
\text { Sheikh } \\
\text { Province }\end{array}$ & 150 & & 0.88 \\
\hline
\end{tabular}


Table (4-a, b and c): Seasonal prevalence of nematode larvae Strongyloides stercoralis in examined crayfish in Sharkia, Dakhlia and Kafr El-Sheikh Provinces.

Table (4 a).

\begin{tabular}{|c|c|c|c|}
\hline Season & \multicolumn{3}{|c|}{ Sharkia Province } \\
\hline & $\begin{array}{c}\text { No. of } \\
\text { examined } \\
\text { specimens }\end{array}$ & $\begin{array}{c}\text { No. of } \\
\text { infected } \\
\text { specimens }\end{array}$ & \% of infection \\
\hline Spring & 22 & 1 & 4.5 \\
\hline Summer & 75 & 2 & 2.6 \\
\hline Autumn & 9 & 0 & 0 \\
\hline Winter & 4 & 0 & 0 \\
\hline Total & 110 & 3 & 2.7 \\
\hline
\end{tabular}

Table (4 b).

\begin{tabular}{|c|c|c|c|}
\hline Season & \multicolumn{3}{|c|}{ Dakhlia Province } \\
\hline & $\begin{array}{c}\text { No. of } \\
\text { examined } \\
\text { specimens }\end{array}$ & $\begin{array}{c}\text { No. of } \\
\text { infected } \\
\text { specimens }\end{array}$ & \% of infection \\
\hline Spring & 59 & 1 & 1.7 \\
\hline Summer & 189 & 6 & 3.2 \\
\hline Autumn & 65 & 1 & 1.5 \\
\hline Winter & 37 & 0 & 0 \\
\hline Total & 350 & 8 & 2.3 \\
\hline
\end{tabular}

Table (4 c).

\begin{tabular}{|c|c|c|c|}
\hline Season & \multicolumn{3}{|c|}{ Kafr El-Sheikh Province } \\
\hline & $\begin{array}{c}\text { No. of } \\
\text { examined } \\
\text { specimens }\end{array}$ & $\begin{array}{c}\text { No. of } \\
\text { infected } \\
\text { specimens }\end{array}$ & \% of infection \\
\hline Spring & 66 & 1 & 1.5 \\
\hline Summer & 75 & 1 & 1.3 \\
\hline Autumn & 7 & 0 & 0 \\
\hline Winter & 2 & 0 & 0 \\
\hline Total & 150 & 2 & 1.3 \\
\hline
\end{tabular}

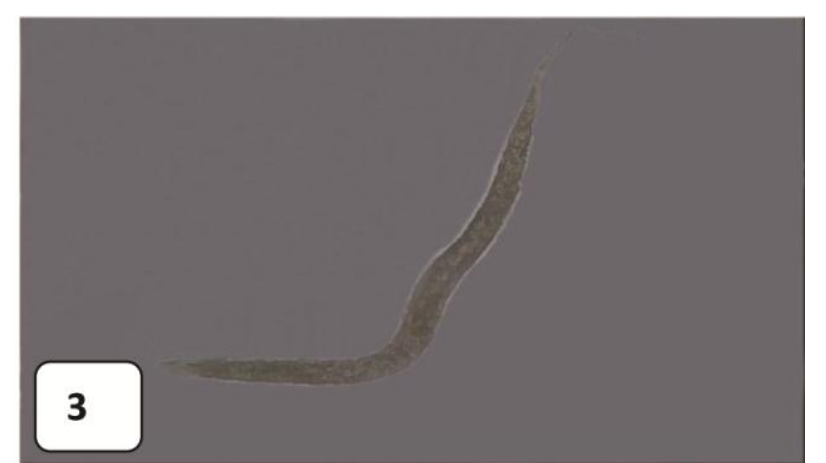

Figure (3): Light micrograph of second rhabditidiform larva of Strongyloides stercoralis (200x)

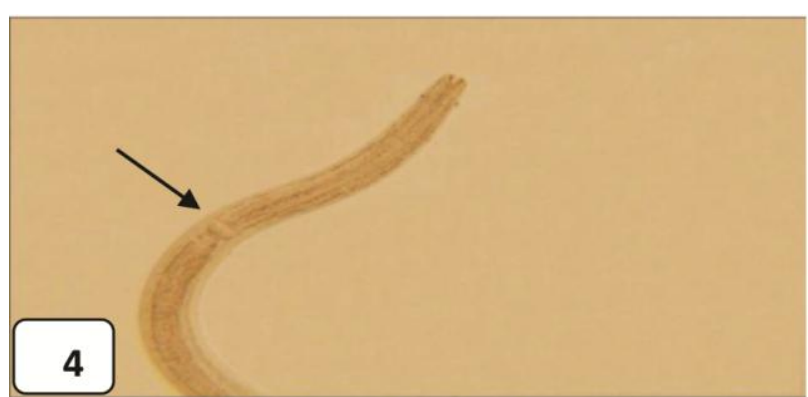

Figure (4): Light micrograph of the anterior region of filariform larva of Strongyloides stercoralis with a prominent genital primordium (arrow), (200x).

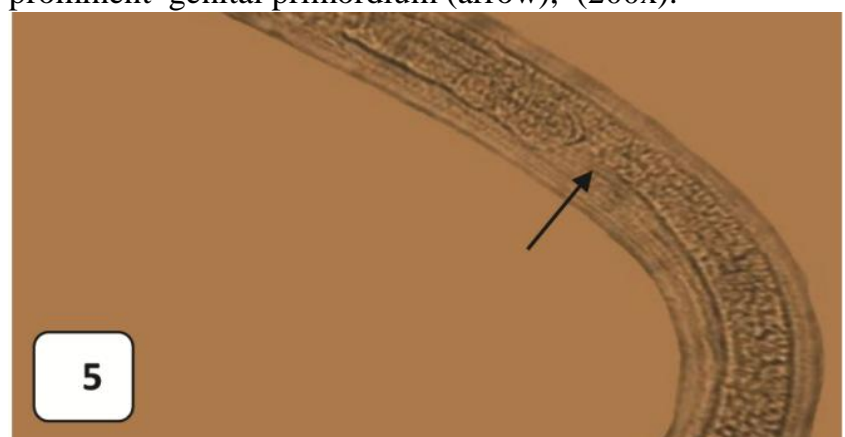

Figure (5): Light micrograph of esophagus -intestine juncture (arrow) in the mid region of the body of filariform larva of Strongyloides stercoralis (200x).

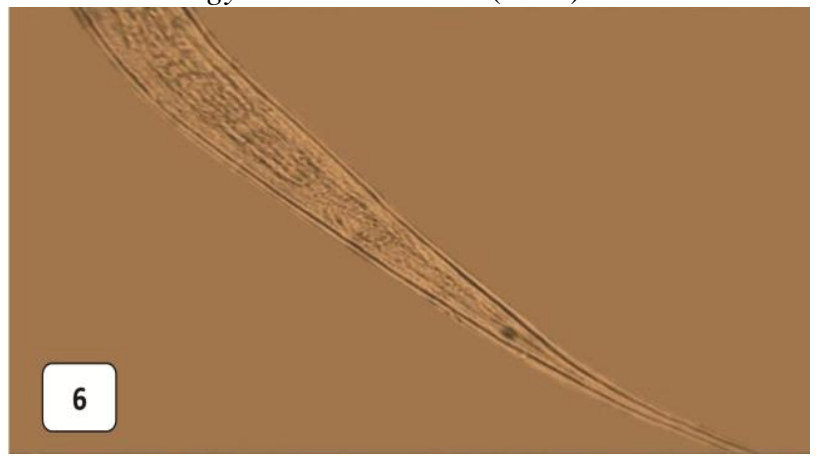

Figure (6): Light micrograph of the tail region of filariform larva of Strongyloides stercoralis (200x).

\section{Discussion}

The purpose of this study was to investigate the presence of parasitic infection in the fresh water crayfish Procambarus clarkii. Crayfish is scaly crustacean animal, which has invaded the territorial water recently and becomes a matter of debate among researchers. Procambarus clarkii now represents a problem to the Egyptian fishermen, farmers and for the River Nile environment. It causes a lot of damage to the fisheries of the Nile by attacking the fry and damaging the nets of the fishermen, also they destroy the roots and shoots of some crops (Soliman et al., 1998). Thus, it represented a new challenge to the local environment. However, as can be observed in other countries, it could be biologically managed through fishing and consumption as a cheap source of food. 
Crayfish acts as reservoir or carrier of many parasites to fish \& man. Several external nematodes have been reported on crayfish, these can be considered to be free-living epibionts with limited impact on host survival (Jones and Lawrence, 2001; Edgerton et al., 2002). Truly parasitic nematodes are normally found internalized within crayfish, either encysted in the muscle or encapsulated on the intestinal wall; to date few parasitic nematodes have been reported in crayfish that acting as intermediate host in all cases ( Longshaw, 2011).These include the human pathogen Gnathostoma spinigerum in Japan and the rat lung worm, Angiostrongylus cantonensis in the USA (Rachford, 1975; Moravec, 2007). Strongyloides stercoralis is a parasitic nematode that is classified under genus Strongyloides which contains 53 species and found as adult in the mucosa of the small intestine in mammals (Speare, 1989). S. stercoralis was identified by (Anderson,1984) and (Frantisek,1994), and this nematode can parasitize human where the adult stage lives in tunnels in the mucosa of the small intestine (Safer et al., 2006). The infected people exhibit a symptomatic infection ,these symptoms include dermatitis, swelling, itching and mild hemorrhage at the site where the skin has been penetrated. S. stercoralis has a very high prevalence in societies where fecal contamination of soil and water was reported (Segarra-Newnham, 2007). Hence, it is a very rare infection in developed economies. In developing countries, like Egypt, it is less prevalent in urban areas than in rural areas where sanitation standards are poor. In this study, the overall infection rate with the larval stages of $S$. stercoralis in examined fresh water crayfish was 13 out of 1474 (0.88\%). Higher percentage of crayfish harbor Angiostrongylus cantonensis larvae was recorded by Raef et al., 2003 ( 2\%, 4 out of 200). In addition, (Fayek et al., 1999) reported that (2.6\%) were infected with one or more parasitic nematode.

A variety of Protozoa moves about or attach to the body surface and gills of crayfish (Johnson, 1983). Ciliated protozoan are commonly associated with crayfish and are found on pleopodes, telsons, gills and carapace (Sprague and Couch, 1971; Morado, 1995).The life cycles are direct and reproduction is normally through binary fission or budding. Ectocommensal infestation of the gills of the crayfish examined in this study with a ciliated protozoan Epistylis cambari was common. In another study, carried out on red swamp crayfish (Procambarus clarkii), found that the elevated presence of Epistylis sp. was associated with low dissolved oxygen concentration and high organic pollution ( Quaglio et al., 2004). The low incidence of E. cambari in the current study could be related to the optimal environmental conditions and water quality. Quaglio et al., (2006) recorded that (12.2\%) were infected with Epistylis sp., where in the present study, the results revealed that ( $0.54 \%$ ) of the examined crayfish were infected with E. cambari Azevedo et al., (2014), described the first record of an epibiont protozoan Epistylis sp. attached to crustacean Ergasilus chelangulatus in Brazil. Ramadan (1997), reported that the protozoan parasites E. cambari caused excessive accumulation of mucus , edema and cellular degeneration of gill filaments of crayfish.

The high rate of infection was observed in the warmer months (summer and spring), providing suitable conditions for the development of crayfish. This time interval is characterized by high ecdysiasts that results in the softening of the exoskeleton of the crayfish, rendering them subject to infestation (Chi et al., 2015 ).

\section{References}

Anderson, R. C. (1984). The origins of zoo parasitic nematodes. Canada. J. Zool., 62: 317-328.

Azevedo, R. K.; Brandao, H.; Abdallah, V.D. and Silva, R. J. (2014). First record of an epibiont protozoan Epistylis sp. (Ciliophora, Peritrichia) attached to Ergasilus chelangulatus ( Ergasilidae) in Brazil. Braz. J. Biol.,74 (2): 460- 463.

Chi, A .P.; Laguna, J. C.; Figueroa, B. R. A.; Cervantes, G. I.; Villegas, O. L. and Avila, G. L. (2015). Prevalence of Haematoloechus pulcher metacercariae ( Digenea: Plagiorchioidea) in the crayfish Cambarellus montezumae in Salazar Lagoon, Estado de Mexico Revista Mexicana de Biodiversidad, 86: 730- 736.

Edgerton, B. F.; Evans, L.H.; Stephens, F.J. and Overstreet,R. M. (2002). Synopsis of fresh water crayfish diseases and commensal organisms. Aquaculture, 206: 57135.

Esch, G. W.; Bush, A. O. and Aho, J. M. (1990). Parasite communities: patterns and process. New York: Chapman and Hall.

Fayek, S. A.; Abd El-Wahab, T. and Raef, A. (1999). New and ached parasite of crayfish procambarus clarkii at Kafr El-Sheikh Province. Alex. J.Vet .Science, 15 (1): 79- 88.

Frantisek, M. (1994) . Parasitic nematodes of fresh water fishes . of Europe. Publisher, Czech Republic.

Hamdy, S. A. H. (2004). Heavy metal bioaccumilative capacity of the red swamp crayfish Procambarus clarkii in the River Nile. Egypt.J. Union Arab Boil, Cairo, 20: 177-199.

Johnson, P. T. (1983). Diseases caused by viruses Rickettsiae, Bacteria and Fungi. In Provenzano A. J. (Ed) the biology of crustacea: Pathobiology. Academic press NY, p. 1-78.

Jones, J. B. and Lawrence, C. S. (2001). Diseases of yabbies (Cherax albidus) in Western Australia. Aquaculture,194: 221- 232.

Lefebvre, F. and Poulin, R. (2005). Progenesis in digenean trematodes: a taxonomic and synthetic overview 
of species reproducing in their second intermediate hosts. Parasitol., 130: 587- 605.

Longshaw, M. (2011). Diseases of crayfish: A review. J. Inver..Pathol., 106: 54- 70.

Morado, J. F. (1995). Ciliate parasites and related diseases of crustacea: a review. Rev. Fish. Sci., 3: 275-354.

Moravec, F. (2007). Some aspects of the taxonomy and biology of adult spirurine nematodes parasitic in fishes: a review. Folia Parasitol., 54: 239- 257.

Quaglio, F.; Morolli, C.; Galuppi, R.; Tampieri, M. P.; Marcer, F. and Rotundo, G. (2004). Pathological investigation on crayfish (Procambarus clarkii, Girard, 1852) from canals in Padana Plain. XV Symposium of the International Association of Astacology. London, Book of the Abstracts, p.45.

Quaglio, F.; Morolli, C.; Galuppi, R.; Bonoli, C.; Marcer, F.;Nobile, L.; Deluise, G. and Tampieri, M. P. (2006). Preliminary investigations of disease - causing organisms in the white clawed crayfish Austropotamobius pallipes complex from streams of Northern Italy. Bull. Fr. Peche. Piscic., 1271-1290.

Rachford, F. W. (1975). Potential intermediate and paratenic hosts for Angiostrongylus cantonensis. J. Parasitol., 61 : 1117- 1119.

Raef, A. M.; Mohamed, A. A.; Mohamed, M. E. M. and Abd El-Maksoud, S. A. (2003). Further studies on the role of some zoonotic parasites in east delta. The Third International Scientific Conference,. Mansoura. Fac.Vet. Med. Mansoura Univ., 29- 30.
Ramadan, F. N. (1997). A study on some protozoa infecting the freshwater crayfish procambarus clarkii in Egypt. Egypt. J. A quat. Biol .and Fish, (2): 359-377.

Safer, D.; Brenes, M.; Dunipace, S. and Schad, G. (2006). Urocanic acid is a major chemoallractant for the skin penetrating parasitic nematode strongyloides stercoralis. Pnas.,104 (5): 1627- 1630.

Segarra-Newnham, M. (2007). Manifestation, diagnosis and treatment of strongyloides stercoralis infection. Annpharmacother, 41 (12): 192- 200.

Soliman, G. N.; EL-Assal, F.; Salah El-Deen, M. and Hamdy, S. A. H. (1998). Habitat, distribution and behavior of the red swamp crayfish procambarus clarkii (Girard, 1852) ( Decapoda: Cambaridae) in the River Nile, Egypt. Egypt. J. Zool., 30:297- 310.

Speare, R. (1989). Identification of species of Strongyloides in : grove di.(ed) strongyloidiasis : a major round worm infection of man. Taylor and Francis, London, 11- 83.

Sprague, V. and Couch, J. A. (1971). An annotated list of protozoan parasites, hyperparasites and commensals of Decapod Crustaceans. J. Protozool., 18: 526-537.

Wetzel, E. J. and Esch, G. W. (1996). Influence of a donate intermediate host ecology on the infection dynamics of Halipegus spp., Haematoloechus longiplexus and Haematoloechus complexus( Trematoda: Digenea). J. Helmintho. Soci. Wash., 63: 1-7.

Whittlock, J. H. (1966). The diagnosis of Veterinary Parasitism.Bailliere Tendall and Cox.London. 